\title{
Elhunyt Magyari Béla kiképzett ürhajós (1949-2018)
}

$\mathrm{M}$ agyari Béla 1949. augusztus 8-án született Kiskunfélegyházán. Édesapja iskolai gondnok, édesanyja adminisztrátor volt. A középiskola elvégzése után 1967-ben, a Kilián György Repülő Műszaki Főiskola hallgatója lett. Két év és sikeres vizsgák után a Szovjetunióban folytatta tanulmányait. 1972-ben hadnagyi rendfokozattal avatták tisztté, utána a légierőkhöz került. 1978-ban századossá léptették elő. 1973-ban III. osztályú, 1977-ben pedig már I. osztályú vadászrepülő pilóta lett. Négy alkalommal tüntették ki. 1977-ben jelentkezett az Interkozmosz program keretében meghirdetett űrhajós kiválasztásra. A kecskeméti ROVKI-ban elvégzett szigorú orvosi vizsgálatok után előbb a legjobb hét, majd a végső négy közé bekerülve, Moszkvába utazhatott, ahol a szovjet orvosok mondták ki a végső szót; Farkas Bertalan mellett ő kezdhette meg 1978. március 20-án Csillagvárosban, a Jurij Gagarinról elnevezett űrhajós kiképzési központban a felkészülést.

A világürbe azonban már csak egyikük, Farkas Bertalan juthatott el. A szovjet-magyar űrrepülés után mindkettőjüket előléptették, Magyari Béla őrnagyi rendfokozatot kapott, és az űrrepülésre való felkészülését a Magyar Népköztársaság Ürhajósa kitüntetéssel ismerték el, Kiskunfélegyházán pedig díszpolgári címet kapott 1980. október 23-án. A sors is némileg kárpótolta, mert míg Farkas Bertalant letiltották a repüléstől, ő egészen 1987-ig évi 25-30 órában, MiG-21-esen hódolhatott szenvedélyének. Szívizom gyulladása azonban véget vetett pilótakarrierjének.

1981-ben ismét beült az iskolapadba, és a Budapesti Műszaki Egyetemen öt év alatt a közlekedési szakon mérnöki diplomát szerzett. Az utolsó két évben az anyagtechnológia felé fordult az érdeklődése és kutatóként dolgozott 1990-ig, közben a Miskolci Müszaki Egyetemen képezte

1. ábra. MiG-21-es pilótafülkéjében az 1970-es évek végén

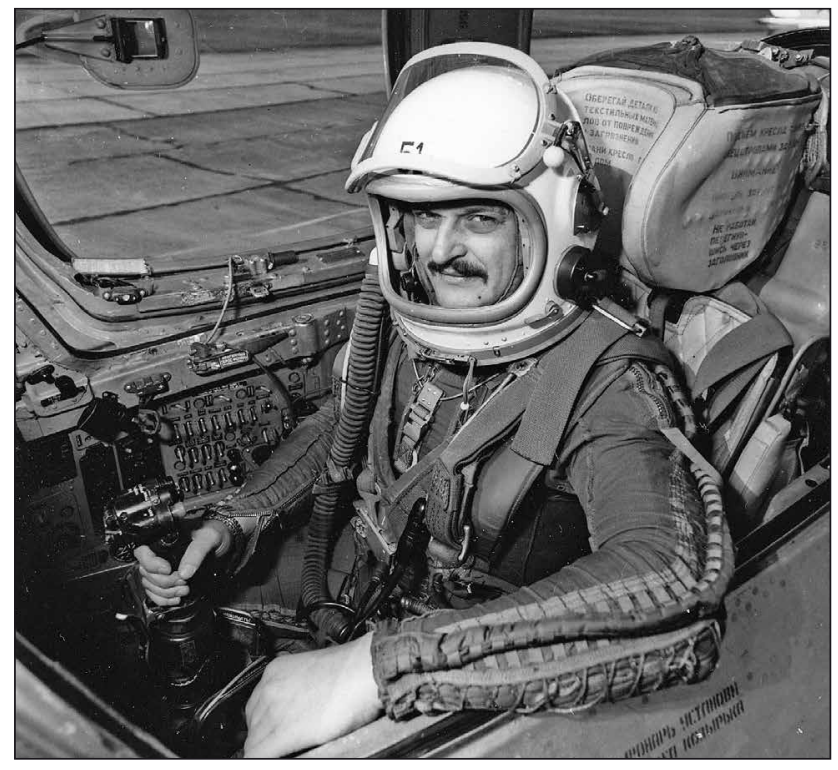

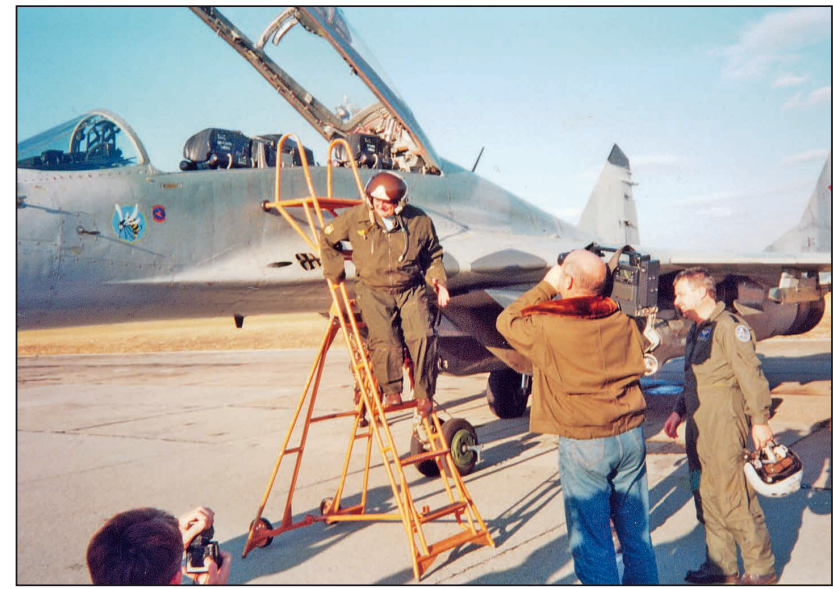

2. ábra. Nagyjából három évtizeddel később. Kamerával Edelényi Gábor operatőr, mellette Siklósi Zoltán alezredes áll

tovább magát. 1990-től a Pénzügyminisztériumban a szovjet csapatok kivonásával foglalkozó titkárság osztályvezetőjeként, a repülőterek hasznosításán dolgozott. Két év múlva visszakerült a honvédséghez, ahol a MiG-21-es vadászgépek fejlesztésével foglalkozott. 1994-től volt tagja a Magyar Ürkutatási Tanácsnak, és elővette félbemaradt, a fémtani kutatások témájú „Al-4,4\%Cu kristályosítása mikrógravitációs körülmények között" című értekezését, amelyet az MTA helyett az egyetemre nyújtott be. 1996-ban sikeresen megvédte kandidatúráját, és ezzel doktori címet szerzett.

1995. május 26-án a magyar űrrepülés 15. évfordulóján ezredessé léptették elő, majd június 1-jétől a Budapesti Műszaki Egyetem honvédelmi csoportvezetőjeként oktatásszervezés volt a feladata. Amikor a csoportot felszámolták, nyolc hónap intenzív angolnyelv-tanulás után, hat hónapig Bosznia-Hercegovinában, az SFOR logisztikai fönökségén osztályvezetőként teljesített szolgálatot. 2000. október 31-én még egyszer vadászgépbe ülhetett. Búcsúrepülésén a magyar légierő 28-as számú MiG-29-esét vezethette néhány percig, Siklósi Zoltán alezredes parancsnoksága alatt.

Egy rövid belügyminisztériumi kitérő után a Katonai Felderítő Hivatal lett a munkahelye. 2001-ben egy soron következő átszervezés alkalmával sok más hivatásos katonával együtt nyugállományba helyezték.

2001. december 10-én a Magyar Asztronautikai Társaság elnökévé választották. Utoljára a Magyar Ürkutatási Iroda munkatársaként tevékenykedett, de az átszervezés itt is utolérte; másodszor is nyugdíjazták.

A közismert és népszerű ember háttérbe vonult, egészsége fokozatosan romlott. Rendkívül erős, igazi pilóta szervezete sokáig állta a harcot, de április 23-ára virradó éjjelen, hosszú betegség után elhunyt.

(Schuminszky Nándor*)

Magyar Asztronautikai Társaság ORCID: 0000-0001-7947-8645 